\title{
Incentive Effects of Community Rating in Insurance Markets: Evidence from Massachusetts Automobile Insurance
}

\author{
Sharon Tennyson \\ Department of Policy Analysis and Management, 252 MVR, Cornell University, Ithaca, NY \\ 14853, U.S.A.
}

Rate regulations in insurance markets often impose cross-subsidies in insurance premiums from low-risk consumers to high-risk consumers. This paper develops the hypothesis that premium cross-subsidies affect risk taking by insurance consumers, and tests this hypothesis by examining the marginal impact of premium subsidies and overcharges on future insurance costs. The empirical analysis uses 1990-2003 rating cell-level data from the Massachusetts automobile insurance market, in which regulation produced large cross-subsidies across cells. Consistent with the hypothesized effects, premium subsidies are found to be significantly related to higher future insurance costs, and the opposite effects are found for premium overcharges.

The Geneva Risk and Insurance Review (2010) 35, 19-46. doi:10.1057/grir.2010.2; published online 13 April 2010

Keywords: rate regulation; moral hazard; automobile insurance; community rating

\section{Introduction}

In many insurance markets regulatory restrictions on underwriting and rate classification limit insurers' ability to charge different insurance premiums to consumers with different risk characteristics. In combination, such regulations have been characterized as community rating restrictions (Pauly, 1970) although that term is not universally applied. The usual stated policy goals of community rating restrictions are to achieve greater rate equity and to promote universal access to insurance. Rate equity concerns arise because competitive underwriting practices cause insurance premiums to vary across consumers. Consumers may perceive insurance price differences as inequitable or prices may be perceived as unaffordable for high-risk consumers (Blackmon and Zeckhauser, 1991). Cross-subsidies may promote universal access by reducing premiums for high-risk consumers, facilitating insurance purchase among this group (Picard, 2008). Community rating restrictions have most notably been imposed in health insurance markets, but similar types of 
restrictions are observed in other insurance markets including automobile insurance. ${ }^{1}$

By limiting premium variation across consumers, community rating restrictions impose cross-subsidies from lower-risk consumers to higher-risk consumers. This paper considers the effect of such premium cross-subsidies on the incentives of consumers who purchase insurance. The point of departure for the study is the recognition that - in many insurance contexts - consumer actions will affect the expected losses from the insured risk. The impact of cross-subsidies is examined by estimating the effect of insurance premium subsidies and overcharges on future insurance costs. The analysis uses a unique panel data set of insurance premiums, insured exposures and premium subsidies by insurance rating category from the regulated Massachusetts automobile insurance market for 1990-2003.

The paper proceeds as follows. The section "Economics of rate crosssubsidies" discusses the theoretical and empirical literature on community rating and related features of insurance rate regulation, and develops the hypothesis to be tested. "Background for the study" provides institutional background on Massachusetts automobile insurance regulation and the regulated premium cross-subsidies. In "Econometric analysis of cross-subsidies" the data set and econometric models used to identify the hypothesized effects are described, and "Estimation results" provides the results of estimation. The final "Conclusion" section presents a summary and implications of the study.

\section{Economics of rate cross-subsidies}

\section{Community rating regulations}

Insurers set premiums based on observable consumer characteristics that are correlated with expected loss experience. Insurers also adjust premiums over time based on an individual's observed loss experience, since losses provide a signal of the expected value of future losses (Boyer and Dionne, 1989). Rate regulations often limit the use of these premium adjustment mechanisms underwriting (sorting by observable characteristics) and experience rating (premium changes based on observed losses) - by requiring insurers to charge the same premiums across broadly defined groups of purchasers. Under a pure community rating system insurers are required to charge the same premium to

\footnotetext{
${ }^{1}$ At least 40 states have introduced community rating restrictions for individual or small group health insurance in the 1990s (Monheit and Steinberg Schone, 2004; Kapur, 2004). Weiss et al. (2010) find that 21 states restrict the use of rating factors in automobile insurance, and 10 states restrict relative rates across driver classes or territories.
} 
all consumers in the insured population, eliminating both underwriting and experience rating from the pricing system. ${ }^{2}$

In automobile insurance, rating restrictions usually impose premium equality across broad classes of consumers but not across the entire insured population. One mechanism used to accomplish this is to restrict the characteristics that insurers are allowed to use in determining rate categories. Age, gender, marital status and location are among the characteristics that are often prohibited for insurer use. In addition, rate category restrictions may be accompanied by limits on the maximum allowable premium differences across rate categories. These mechanisms limit both premium variation across groups (underwriting), and the extent to which premiums can adjust in response to differential loss experience (experience rating), and create subsidies from lower-risk drivers to higher-risk drivers within and across rate categories.

\section{Theoretical issues}

The potential distortions to insurance markets and the associated efficiency losses from insurance rating restrictions have been well documented theoretically. ${ }^{3}$ Drivers who receive insurance premium subsidies face less than the true marginal cost of insurance and may purchase more insurance than under competitive pricing; drivers who face premium overcharges may similarly purchase less insurance than is socially desirable (Pauly, 1970). More specifically, it can be shown that if risk characteristics are observable or risk categorization is not too costly (even if imperfect), restricting allowable rate categories will always lead to efficiency losses (Crocker and Snow, 1986).

Competitive responses of insurers may reduce or eliminate the effects of rate category restrictions and thus the associated efficiency losses. For example, insurers may respond by offering a menu of policies to induce customers to sort themselves into high- and low-risk categories, as predicted by certain theoretical models of adverse selection (Rothschild and Stiglitz, 1976; Wilson, 1977; Riley, 1979). Alternatively, insurers may circumvent regulatory restrictions by categorizing risks based on individuals' consumption of other goods that are correlated with risk (Crocker and Bond, 1991).

\footnotetext{
${ }^{2}$ New Jersey's Individual Health Coverage Program (IHCP) requires pure community rating in the market for individual health insurance. Near pure community rating is required in Vermont and New York. See Monheit et al. (2004) and Buchmueller and DiNardo (2002) for more details on these states' restrictions.

${ }^{3}$ See discussions in Pauly (1970), Abraham (1985), Rea (1992), Harrington and Doerpinghaus (1993).
} 
Perhaps for these reasons, insurers' ability to determine risk categories, premiums and quantities are often limited by community rating regulations. Such restrictions reduce the possibilities for sorting or selecting consumers through contract offerings, and make it difficult for low-risk consumers to avoid paying premium overcharges. This raises at least the theoretical possibility that rating restrictions will cause the insurance market to unravel, as more high-risk consumers enter and low-risks exit rather than pay the premium charges associated with providing cross-subsidies.

Nonetheless, there are market circumstances in which premium crosssubsidies from low risks to high risks represent a constrained efficient outcome. ${ }^{4}$ One important circumstance is when transactions costs, limited liability or government programmes cause some individuals to remain uninsured while participating in the risky activity (Shavell, 1986). If the uninsured impose negative externalities on other market participants, then an efficiency argument for premium cross-subsidies may arise.

In the automobile context uninsured drivers impose negative externalities on others in the form of increased accident risk and accident costs. Moreover, under limited liability it can be shown that high-risk drivers are the most likely to forego liability insurance (Shavell, 1986). Keeton and Kwerel (1984) and Smith and Wright (1992) have shown that if a sufficiently large proportion of high-risk drivers is uninsured, and if high-risk drivers make up a sufficiently small percentage of drivers, premium cross-subsidies from low-risk to high-risk drivers can be Pareto improving. These gains come from the fact that subsidized high-risk drivers may purchase more insurance under communityrated premiums than they would under competitive (risk-based) premiums, reducing the external costs borne by insured drivers.

This type of reasoning may provide a theoretical justification for insurance rate cross-subsidies. ${ }^{5}$ However, it is based on models in which consumers' risk is fixed and exogenously determined. Premium subsidies may also distort consumers' safety incentives. Thus, the theoretical argument for rating restrictions rests on the assumption that consumers' decisions do not significantly affect insured losses, or on the assumption that decisions affecting risk are not sensitive to insurance prices. In automobile insurance this is unlikely to be the

\footnotetext{
${ }^{4}$ Cross-subsidies from low risks to high risks and resulting reductions in insurance coverage for low risks may arise in competitive equilibrium, as a response to adverse selection (Wilson, 1977; Crocker and Snow, 1986).

${ }^{5}$ Other justifications for premium cross-subsidies include rate equity, risk spreading, income redistribution and premium stability (Pauly, 1970; Abraham, 1985; Blackmon and Zeckhauser, 1991; Rea, 1992; Picard, 2008). Cross-subsidies are nonetheless inefficient forms of riskspreading or redistribution if they distort insurance decisions.
} 
case. ${ }^{6}$ Drivers make decisions regarding car ownership, the number and type of cars to own, and housing or career choices that involve or require more driving. If rate regulations reduce the extent to which premiums vary with the risk outcomes of these decisions, regulation may distort consumer risk-taking.

Drivers also make continuing choices that affect accident risk, such as the amounts and types of driving to do and the care they take in driving. Because rate restrictions distort the responsiveness of future premiums to accident experience, drivers' incentives to make choices that reduce accident risk may be distorted. On the margin, drivers who receive premium subsidies face less than the true marginal cost of these decisions, and may make decisions that yield higher risk. Drivers who pay premium overcharges face more than the true marginal cost of these decisions and may make decisions that yield lower risk. This effect of premium cross-subsidies is predicted to increase insured losses of high-risk drivers and reduce losses of low-risk drivers. ${ }^{7}$ These distortions to drivers' safety incentives imply that the efficiency effects of community rating restrictions must take into account any effects of cross-subsidies on the behaviors of insured consumers.

A differential effect on the incentives of overcharged vs. subsidized drivers occurs because the impact of future experience rating is greater for a driver who pays an overcharge. ${ }^{8}$ Experience rating adjustments are applied as a percentage increase in the current rate; thus the overcharged driver experiences a greater effective premium increase for accidents than the subsidized driver, and has a greater incentive to reduce accident risk. This is the case even if experience rating fully applies to both driver groups. This is demonstrated more formally in the Appendix using a simple illustrative model of driver safety choice under rate regulation. When regulation limits the effects of experience rating for high-risk drivers, the incentive differences between low-risk and high-risk drivers will be even greater.

\section{Empirical evidence}

Much of the empirical literature evaluating the impact of community rating restrictions has focused on the extent to which rate cross-subsidies distort

\footnotetext{
${ }^{6}$ Studies of regulated bonus-malus rating systems in other countries provide confirmatory evidence that driving, insuring and claiming behaviors are sensitive to the price of insurance (Dionne and Ghali, 2005; Dionne, 2002).

${ }^{7}$ The same effect could also arise due to changes in incentives to file insurance claims (legitimate or fraudulent), if filing decisions are affected by concerns about changes in premiums.

${ }^{8}$ Danzon and Harrington (2001) make a similar argument regarding the reduced impact of experience rating in workers compensation insurance when rates are suppressed below competitive levels.
} 
consumers' insurance purchase decisions. Whether community rating restrictions lead to market unravelling has been studied in health insurance markets for small employer groups. Most econometric studies find small or no statistically significant effects (Buchmueller and DiNardo, 2002; Monheit and Steinberg Schone, 2004; Simon, 2005), although case studies of New Jersey's community-rated programme for individual health insurance find more mixed evidence of market size decreases (Swartz and Garnick, 1999; Monheit et al., 2004). The observed price elasticity of health insurance purchase rates may be muted by insurers' ability to offer different contract types, however, as Buchmueller and DiNardo (2002) find some evidence of risk-based contract sorting in these markets. ${ }^{9}$

Restrictions on rate categories in automobile insurance have not been studied as extensively. Studies of automobile insurance in Canada found that unisex rating restrictions would reduce insurance coverage by female (low-risk) drivers (Dahlby, 1983, 1992). Bartlett et al. (1999) argue that rating restrictions cause both insurers and low-risk consumers to exit the insurance market, and provide historical evidence from several markets including automobile insurance.

A related literature argues that rate regulation may affect incentives in a variety of ways that lead to higher insurance costs. The focus of this literature has been as much on insurer incentives as on those of the insured, and on regulatory suppression of average premium levels rather than on premium cross-subsidies. ${ }^{10}$ Nonetheless, a growing body of empirical evidence supports the idea that stringent rate regulation leads to higher average insurance costs. In case studies of specific state automobile insurance markets, Tennyson et al. (2002) and Grace, Klein and Phillips (2002) argue that rate regulation in Massachusetts and South Carolina, respectively, leads to higher loss costs and claim levels.

Other studies explore the hypothesis using panel data. Harrington and Danzon (2000) use state-level data on workers compensation insurance for 1984-1990, and find that regulatory rate suppression is linked to higher loss cost growth in a state. Regan et al. (2008) test a similar hypothesis using a panel of state automobile insurance data for the period 1990-1998. These authors find that average loss costs are higher in regulated states that have larger residual markets. In a study using class-level data, Danzon and Harrington (2001) hypothesize that workers compensation rating classes for

\footnotetext{
${ }^{9}$ Finkelstein and Poterba (2004) find some evidence of such sorting in annuities markets, and Finkelstein et al. (2006) show that estimates of market dislocations can be reduced by about half if the endogenous response of insurance contracts to rating restrictions is taken into account.

${ }^{10}$ See, for example, Harrington (1991), Blackmon and Zeckhauser (1991), Bartlett et al. (1999), Tennyson (1997).
} 
which premiums are suppressed below competitive levels will have higher loss cost growth due to distortions in insured safety incentives. Using data from eight states for 1985-1991, and after removing outliers and collapsing the data into two time periods to reduce loss growth volatility, their empirical findings strongly support the hypothesis. The results of all of these studies provide evidence that regulatory price distortions lead to higher insurance loss costs.

\section{Contribution of the paper}

This paper examines the marginal effects of premium cross-subsidies on the incentives of subsidized and overcharged drivers in an automobile insurance market, to test the prediction from economic theory that premium cross-subsidies may affect the risk-taking behavior of insured drivers. Drivers who receive premium subsidies are predicted to have reduced incentives to drive safely, and drivers who pay premium overcharges are predicted to have increased incentives to drive safely. This leads to the following hypothesis:

Hypothesis 1: Premium subsidies will lead to higher future insurance costs and premium overcharges will lead to lower future insurance costs, all else equal.

Data from the regulated Massachusetts automobile insurance market are used to test this hypothesis. The data are generated from a period in which the state insurance commissioner controlled virtually all aspects of automobile insurance pricing, underwriting and sales, and the regulatory mechanism generated explicit premium subsidies from low-risk to high-risk drivers. To provide necessary background for the empirical tests, selected features of the Massachusetts regulatory system are outlined in the next section.

\section{Background for the study}

\section{Massachusetts automobile insurance regulation}

Until 2008, automobile insurance rates in Massachusetts were established annually through a public hearing process overseen by the state insurance commissioner. ${ }^{11}$ The rates determined through the hearings were charged by all

\footnotetext{
${ }^{11}$ Automobile insurance rate regulation is governed by Massachusetts G.L.c.175E. The regulations described here began in the late 1970s, and Stone (1978) describes the expansion
} 
Table 1 Major features of rate regulation in Massachusetts automobile insurance

Community rating-style restrictions

Restrictions on the use of rating variables

Age, gender, marital status prohibited

Restrictions on relative rates across rating categories

Rate differences explicitly tempered

Restrictions on maximum rate increases by rating category

Relative rate increases explicitly capped

Restrictions on residual market rates

Premium surcharges prohibited for highest risk drivers

Regulations supporting community rating

Rates set annually by state insurance commissioner

State rates charged by all insurers

Mandatory offer rule

Restrictions on policy denial/cancellation

Compulsory automobile insurance

Insurance required of all drivers

Sources: Stone (1978), Rottenberg (1989), Derrig (1993), Yelen (1993), Tennyson et al. (2002).

firms writing in the state - irrespective of differences in operating costs. Insurers could seek the approval of the insurance commissioner to charge lower rates than the state-set rates, but such deviations were very uncommon. State rates were established for each individual rating cell, and the rating cells were defined by state-determined rating classes and territories. The state-set rates included explicit cross-subsidies between cells.

Table 1 summarizes the elements of the Massachusetts system that supported the rate cross-subsidies. Insurer underwriting was constrained by strict limits on the variables that could be used to classify driver risk. A total of nine driver rating classes were allowed, with drivers classified only by driving experience, drivers' training and use of car. Age, gender and marital status were specifically prohibited from use as rating variables. ${ }^{12}$ Rating territories were also broadly

of regulatory enforcement at that time. For further discussion of the regulations see Rottenberg (1989), Derrig (1993), Yelen (1993) and Tennyson et al. (2002). Reforms instituted in 2008 allow insurers to determine their own rates subject to state prior approval, and modify the operation of the residual market.

12 The use of a separate rating category for senior citizens is an exception. 
defined, and determined through a regulatory hearing process. ${ }^{13}$ The result was a far coarser rate classification system than in other automobile insurance markets. ${ }^{14}$ Insurers were not permitted to deviate from the prescribed classterritory definitions.

The state rate-setting formula systematically leveled average insurance premiums across driver classes and territories, through a process known as tempering and capping of rates. Tempering puts constraints on the differences in annual rate levels across the rating cells. Capping restricts the annual increase in rates for any rating cell to be no more than a specified percentage above the average statewide increase. The tempering and capping of rates significantly limited the use of underwriting and experience rating in premium determinations.

Rates were further capped and tempered for the highest risk drivers due to regulations requiring that drivers insured in the residual market pay the same premium they would pay if insured voluntarily. Access to insurance for highrisk drivers was further protected by restrictions on insurers' ability to refuse insurance or cancel a policy. Undesirable policies could be ceded to the residual market facility, but insurance could not be refused or cancelled due to poor loss experience.

Additional premium distortions arose due to the manner in which state regulations required residual market operating deficits to be added into premiums. The total deficit amount was divided equally across insured exposures and added as a flat dollar amount to the rate for each rating cell (not in relation to the cell's premium nor to its contribution to the residual market). This procedure resulted in drivers in low-risk cells paying a higher proportion of the residual market deficit than that which originated from the drivers in the cell. It also meant that a higher percentage of the premium paid by low-risk cells stemmed from contributions to the residual market deficit.

Regulatory cross-subsidies were supported by a strong compulsory insurance law, which reduced the ability of drivers to avoid premium overcharges by exiting the insurance market. Compulsory coverage included bodily injury liability, property damage liability, personal injury, medical expense and uninsured motorist coverage. Liability insurance components compensate other drivers for property damage and major bodily injury losses incurred as a result of the fault of the insured driver. The other components of compulsory coverage compensate the insured driver (and passengers) for her

\footnotetext{
${ }^{13}$ Towns are assigned to territory by average loss costs rather than by fiat; territories are adjusted every 2 years.

${ }^{14}$ See Finger (2006) for examples of automobile insurance rate classification systems. Finger notes that the standard industry classification plan contains 217 driver classes.
} 
own injury losses due to automobile accidents. First party property damage (collision and comprehensive) insurance, that compensates the insured driver for vehicle-related losses, were optional under state law.

\section{Cross-subsidies in the rates}

Because insurers were required to use standardized driver classes and rating territories and the state-determined average insurance premiums for each classterritory rating cell, state-level data are available annually by individual rating cell. Data by rating cell are taken from copies of regulatory filings of the state Automobile Insurers Bureau (AIB). ${ }^{15}$ Data on the regulated premiums and actuarial estimates of the true cost-based premiums for each rating cell are used to construct estimates of the average subsidy or surcharge in the premium for the cell.

Estimates of the cost-based premium are used as a proxy for the average cost of insurance within each cell. ${ }^{16}$ Cost-based premiums are determined by the expected value of losses incurred plus insurer expenses, with proportional loading factors that incorporate tax and profit allowances (Fairley and Chang, 1979). The formula for the cost-based premium (C) is shown in Eq. (1). $L$ denotes expected losses, $E$ denotes insurer expenses, $\pi$ denotes the profit allowance and $\tau$ the insurer's tax rate.

$$
C=\frac{(L+E)(1+\pi)}{1-\tau} .
$$

The expected value of losses are developed by applying standard actuarial methods to incurred loss data, using techniques approved by the Massachusetts insurance commissioner (Fairley and Chang, 1978; AIB, 1998). These costbased premium data are the best available estimates of the costs of insurance for each cell, and are the cost values to which tempering, capping and other constraints are applied to achieve the state-set premium for each rating cell. Although this cost measure includes expenses, profits and tax loadings, the

\footnotetext{
${ }^{15}$ Data are obtained from Automobile Insurers Bureau of Massachusetts (1991-2005). As part of the regulatory hearing process, each year the Massachusetts AIB submitted a filing on behalf of all insurers in the state, using industry average data obtained from the independent statistical agency, Commonwealth Automobile Reinsurers. Regulated rates were determined based on industry averages.

${ }^{16}$ The estimated cost-based premiums are constructed by the AIB, not by the author.
} 
Table 2 Subsidy patterns by class-territory rating cell for compulsory automobile insurance, 2003

\begin{tabular}{lcrrrr}
\hline & $\begin{array}{c}\text { Number of } \\
\text { cells }\end{array}$ & $\begin{array}{c}\text { Insured } \\
\text { vehicles }\end{array}$ & $\begin{array}{c}\text { Average } \\
\text { premium }\end{array}$ & $\begin{array}{c}\text { Average cost-based } \\
\text { rate }\end{array}$ & $\begin{array}{c}\text { Average } \\
\text { subsidy }\end{array}$ \\
\hline Receiving subsidy & 108 & 566,890 & $\$ 1,302.39$ & $\$ 1,754.36$ & $\$ 451.97$ \\
$\begin{array}{l}\text { Not receiving } \\
\text { subsidy }\end{array}$ & 134 & $3,425,295$ & $\$ 808.92$ & $\$ 756.48$ & $-\$ 52.44$ \\
\hline
\end{tabular}

Source: Author's calculations using data from Actuarial Notice: Subsidies in the Rates, Automobile Insurers Bureau of Massachusetts, 2003.

method by which the loadings are incorporated does not distort the relative cost of insurance across cells. ${ }^{17}$

The difference between the regulated premium and the cost-based premium for each rating cell determines whether drivers in a rating cell receive a premium subsidy or pay an overcharge, on average. If this difference is positive the rating cell receives a premium subsidy; if this difference is negative the rating cell pays a premium overcharge. The average premium subsidy or overcharge amount is the magnitude of the difference between the cost-based premium and the regulated premium.

The Massachusetts regulations produced significant premium cross-subsidies across driver rating cells. Table 2 summarizes the extent and scope of the crosssubsidies for the year 2003. ${ }^{18}$ The table compares average prices and costs for compulsory automobile insurance for rating cells receiving a subsidy vs. those that did not. ${ }^{19}$ The table reports the average premium set by the state, the average cost-based premium, and the average subsidy amount for these two groups. Subsidy amounts are defined as positive in the table, and overcharge amounts are defined as negative.

The table shows that 108 of the 243 rating cells are subsidized in 2003, representing 14.3 per cent of insured cars. Subsidies tend to go to higher risk cells: subsidized rating cells have an average cost of $\$ 1754.36$, while unsubsidized cells have an average cost of $\$ 756.48$. Drivers in subsidized cells pay higher average insurance premiums than unsubsidized cells ( $\$ 1302.39$ vs.

${ }^{17}$ Loss development and expense factors were required to be common across cells, and were agreed to as part of the regulatory hearing process.

${ }^{18}$ Sources and data on premiums and subsidies are described fully in the next section of the paper.

${ }^{19}$ Premiums for individual drivers may vary from the rating cell average due to percentage experience rating adjustments based on accident experience, but the magnitude of these adjustments were modest. Experience rating adjustments were determined by the state rather than by insurers. For years 1996 and prior, the adjustment was 5 per cent per step; for the later years in the sample it was 6 per cent. 
The Geneva Risk and Insurance Review

30

Table 3 Subsidy patterns by class and territory for compulsory automobile insurance, 2003

\begin{tabular}{lrrr}
\hline & All classes & Inexperienced classes & Other classes \\
\hline $\begin{array}{l}\text { All territories } \\
\text { Percentage of cells subsidized }\end{array}$ & & & \\
Average premium & 44.44 & 51.85 & 29.63 \\
Average subsidy & $\$ 1,028.24$ & $\$ 1,247.47$ & $\$ 589.78$ \\
& $\$ 171.74$ & $\$ 250.50$ & $\$ 14.23$ \\
$\begin{array}{l}\text { Boston territories } \\
\text { Percentage of cells subsidized }\end{array}$ & & & \\
$\begin{array}{l}\text { Average premium } \\
\text { Average subsidy }\end{array}$ & $\$ 1,147.20$ & $\$ 1,359.26$ & 60.00 \\
& $\$ 295.14$ & $\$ 400.28$ & $\$ 723.09$ \\
$\begin{array}{l}\text { Non-Boston territories } \\
\text { Percentage of cells subsidized }\end{array}$ & & & \\
$\begin{array}{l}\text { Average premium } \\
\text { Average subsidy }\end{array}$ & 32.03 & 42.16 & \\
\hline
\end{tabular}

Source: Author's calculations using data from Actuarial Notice: Subsidies in the Rates, Automobile Insurers Bureau of Massachusetts, 2003.

\$808.92), but the underlying cost differences are twice that of the premium differences. Subsidized cells receive an average subsidy of $\$ 451.97$, while the average excess premium among overcharged cells is $\$ 52.44$. The subsidy and overcharge amounts balance out over the driving population due to the smaller numbers of drivers in subsidized cells.

Table 3 provides further details on the direction of cross-subsidies. The table reports the average premium, average subsidy (or overcharge) amount, and the percentage of rating cells that were subsidized by major class and territory groupings for compulsory insurance in 2003. The data demonstrate that drivers in the Boston territories and inexperienced drivers were those most likely to receive a subsidy. Overall, 51.85 per cent of inexperienced driver cells are subsidized whereas only 29.63 per cent of other cells receive a subsidy. In Boston, 65.56 per cent of rating cells are subsidized but in all other territories the subsidized percentage is only 32.03 . However, some proportion of drivers in every major grouping receive subsidies. Within Boston, subsidies are fairly evenly split across inexperienced and experienced drivers, with 68.33 per cent of inexperienced driver cells and 60.00 per cent of other rating cells receiving a subsidy. Outside of Boston, 42.16 per cent of inexperienced driver rating cells receive a subsidy, whereas only 11.76 per cent of other driver cells are subsidized.

The amounts of subsidy or overcharge also follow these same patterns. On average, all Boston driver cells receive substantial subsidy amounts, averaging $\$ 295.14$. Boston subsidies are much higher for inexperienced drivers $(\$ 400.28)$ than for other drivers (\$84.86). Similarly, inexperienced driver cells overall 
Table 4 Subsidy patterns over time by class-territory rating cell for compulsory automobile insurance, 1990-2003

\begin{tabular}{|c|c|c|c|}
\hline & $\begin{array}{l}\text { Always } \\
\text { subsidized }\end{array}$ & $\begin{array}{c}\text { Always } \\
\text { overcharged }\end{array}$ & $\begin{array}{l}\text { Varying subsidy } \\
\text { status }\end{array}$ \\
\hline Number of rating cells & 79 & 57 & 107 \\
\hline Mean number of years subsidized (within cell) & 14 & 0 & 6.5 \\
\hline Mean of subsidy or overcharge (within cell) & $\$ 610.66$ & $\$ 43.32$ & $\$ 14.31$ \\
\hline $\begin{array}{l}\text { Mean standard deviation of subsidy or overcharge } \\
\text { (within cell) }\end{array}$ & $\$ 145.53$ & $\$ 17.82$ & $\$ 65.15$ \\
\hline $\begin{array}{l}\text { Mean inter quartile range of subsidy or overcharge } \\
\text { (within cell) }\end{array}$ & $\$ 148.80$ & $\$ 20.82$ & $\$ 79.27$ \\
\hline
\end{tabular}

Source: Author's calculations using data from Actuarial Notice: Subsidies in the Rates, Automobile Insurers Bureau of Massachusetts, for years 1990-2003. Monetary values are in constant 2003 \$.

receive an average subsidy of $\$ 250.50$, but subsidies are smaller outside of Boston where inexperienced driver cells receive an average subsidy of $\$ 162.39$. Experienced drivers outside of Boston pay an average overcharge of \$27.32 in 2003.

There is nonetheless considerable variation over time in subsidy patterns and amounts at the level of the individual class-territory rating cell. Table 4 documents the variation in annual subsidies at the rating cell level for 1990-2003. The table shows that 79 rating cells received a premium subsidy in every year of this time period, whereas 57 cells paid a premium overcharge in every year. This means that 107 rating cells, nearly one-half of the total, move between subsidy status and overcharge status during the time period. Among these cells the mean number of years that a cell is subsidized is 6.5 (out of 14).

The table also demonstrates that there is substantial variation over time in subsidy and overcharge amounts within each cell. Among the cells that are subsidized in every year 1990-2003, the mean subsidy amount is $\$ 610.66$ over the period. Among cells that are overcharged in every year 1990-2003, the mean overcharge amount is $\$ 43.32$. However, the within-cell standard deviation of subsidy amount in the subsidized group averages \$145.53, and the mean intertemporal interquartile range of cell subsidy amounts is $\$ 148.80$. Among overcharged cells, the within-cell standard deviation of overcharge amount over time is $\$ 17.82$ and the interquartile range is $\$ 20.82$. Among cells that change subsidy status during the study period, the variation in subsidy or overcharge amounts is even greater. On average these cells receive a modest subsidy of $\$ 14.31$, but the within-cell standard deviation and interquartile range of subsidy or overcharge amounts are $\$ 65.15$ and $\$ 79.27$, respectively. 


\section{Econometric analysis of cross-subsidies}

\section{Sample construction}

Annual data for the time period 1990-2003 are obtained from the AIB rate filings, scanned and converted to a cell-by-year database suitable for analysis. Available data include the state-set premium levels, actuarial estimates of the cost-based premiums, and the number of car-years insured in each rating cell in each year. Due to the use of lagged variables, the empirical analysis is undertaken for 1991-2003. To create a balanced panel, only data from territories 1 to 26 are included in the analysis because territory 27 was created in the middle of the sample period. ${ }^{20}$ Thus the sample of observations contains 234 rating cells for 13 years, a total of 3,042 observations.

The analysis makes use of data for compulsory insurance only. This eliminates any effects on costs that could arise due to differences over time in the characteristics of drivers who purchase optional insurance. Compulsory insurance coverage limits are determined by the state, and the cost and premium data reflect these minimum coverage amounts. The coverage limits remained constant (in nominal terms) over the sample period. ${ }^{21}$ All monetary values in the data are converted to 2003 dollars using the all-items Consumer Price Index.

\section{Empirical models}

The estimated models of insurance costs take the following basic form:

$$
\operatorname{Ln}\left(\operatorname{Cost}_{i j t}\right)=\alpha_{0}+\alpha_{1} \operatorname{Subsidy}_{i j t-1}+\alpha_{2} X_{i j t}+\gamma_{1}{ }^{\prime} D_{t}+\mu_{i j}+\varepsilon_{i j t},
$$

where the subscript $i$ denotes driver class, $j$ denotes territory and $t$ denotes year. The data are analyzed at the level of the rating cell and each cell is uniquely identified by an $i j$ subscript in each year. $\operatorname{Ln}\left(\operatorname{Cost}_{i j t}\right)$ is the natural log of the cost-based premium for compulsory insurance. Subsidy $y_{i j t-1}$ denotes the measure of subsidy or overcharge for each cell in the previous year, as previously described. $X_{i j t}$ denotes other characteristics of the rating cell. $D_{t}$ are dummy variables for year. The $\alpha$ and $\gamma$ terms are parameters to be estimated, while $\mu_{i j}$ is a cell-specific fixed effect and $\varepsilon_{i j t}$ is a random error term.

${ }^{20}$ Results are similar when territory 27 is included in the analysis. Because territory 27 was created by splitting territory 1 into two territories, I also tried eliminating territory 1 as well as territory 27. Results are again similar.

${ }^{21}$ Compulsory limits are $\$ 20,000$ per person and $\$ 40,000$ per accident for bodily injury liability, uninsured motorists' coverage; $\$ 5,000$ for property damage liability; $\$ 8,000$ for personal injury protection. 
The key explanatory variable of interest in the model is Subsidy $y_{i j t-1}$, a variable to capture the impact of premium subsidies or overcharges. Lagged rather than current values of subsidies are used because any behavioral responses induced by subsidies will be reflected in increases in accident costs for the current year, leading to upward revisions in cost-based premiums for the following year.

A first set of models explores the effect of subsidies on insurance costs using measures of cell subsidy status. The first measure is an indicator variable set equal to one if a rating cell receives a subsidy in a given year, and set equal to zero otherwise. The second is the percentage of drivers in the rating cell who receive a premium subsidy.

A second set of models uses subsidy and overcharge amounts. One version of these models includes a single variable representing the simple difference between the cost-based premium and the regulated premium, lagged one period. This variable is negative for rating cells that are overcharged and positive for rating cells that receive a subsidy in each year, and will vary linearly in the subsidy or overcharge amount. This model specification assumes a symmetric response of costs to subsidies and overcharges.

Another version of these models includes separate variables for subsidy and overcharge amounts. The (lagged) subsidy variable is set equal to zero for rating cells and years in which no subsidy is received, and equal to the subsidy amount in cases where a subsidy is received. The (lagged) overcharge variable is set equal to zero for rating cells and years in which no overcharge is paid, and equal to the overcharge amount in cases where an overcharge is paid. In this specification, the overcharge amount is defined as a positive number. Redefined in this way, the overcharge variable is expected to be negatively related to cost growth (i.e. to have the opposite sign of the subsidy variable).

Although rating cell fixed effects account for the fact that costs may differ systematically across cells, they do not account for the possibility that these costs themselves may be spuriously correlated with the choice of subsidy or overcharge. Several time-varying state controls are included to account for this. All of the empirical models include as a control variable the annual change in the number of cars insured for compulsory liability insurance in the rating cell. Changes in the number of insured cars per territory population are likely to change the risk composition of the rating cell and this may affect average costs. The predicted effect of growth in the rating cell on risk composition is ambiguous since there are many reasons that rating cell size could change, including changes in the composition of the state population. However, because high-risk drivers are more likely to be uninsured (Shavell, 1986), if growth in the number of cars insured in a rating cell represents increases in insured driving then the effect of this variable on insurance costs will be positive. 
The Geneva Risk and Insurance Review

34

Table 5 Summary statistics for regression sample, 1991-2003 data

\begin{tabular}{lccc}
\hline Variable & $N$ & Mean & Std. dev. \\
\hline Cost-based premium & 3,042 & $\$ 1,305.53$ & $\$ 791.44$ \\
Regulated premium & 3,042 & $\$ 1,101.75$ & $\$ 470.67$ \\
Percentage of cars insured for optional coverage & 3,042 & 0.5984 & 0.1362 \\
Percentage of growth in insured cars & 3,042 & 0.0649 & 0.6369 \\
Lag amount of subsidy or overcharge & 3,042 & $\$ 195.86$ & $\$ 394.32$ \\
Lag amount of subsidy & 3,042 & $\$ 213.10$ & $\$ 383.61$ \\
Lag amount of overcharge & 3,042 & $\$ 17.24$ & $\$ 31.33$ \\
Lag subsidy indicator & 3,042 & 0.5713 & 0.4950 \\
Lag percentage subsidized within cell & 3,042 & 0.5660 & 0.3665 \\
\hline
\end{tabular}

Source: Author's calculations using data from Actuarial Notice: Subsidies in the Rates. Automobile Insurers Bureau of Massachusetts, for years 1990-2003. Monetary values are in constant 2003 \$.

In some specifications the rate of optional insurance purchase (the ratio of collision car-years to liability car-years) lagged one year, and the lagged value of the regulated insurance premium for compulsory coverage, are also included as controls. These variables are included to account for other time-varying characteristics associated with rating cell composition that may affect rating cell average costs. Table 5 reports summary statistics for the regression variables.

A final set of models includes a separate linear time trend for each class and rating territory to account for the possibility that other unmeasured trends could be correlated with subsidies or overcharges. This fully specified model estimates whether a rating cell that receives a premium subsidy or overcharge experiences a changes in insurance costs relative to all other cells, relative to the cell's underlying cost that is common across all years, and relative to anything else in the cell's class or territory that may cause its insurance cost to increase or decrease linearly over time relative to other classes and territories.

\section{Estimation methods}

Use of the subsidy or overcharge amounts in the empirical models of insurance costs may lead to endogeneity problems because these amounts are constructed using the cost data. Use of lagged values of these amounts is intended to ameliorate that problem to some extent. An issue that still remains is the potential for feedback effects of subsidies or overcharges on insurance costs. Because subsidies are observed to go to high-risk (high-cost) driver groups, a high level of subsidy/overcharge in year $t-1$ that leads to higher/lower costs in year $t$ may then lead to a high level of subsidy/overcharge in year $t+1$. This feedback process in the presence of fixed effects implies that the subsidy 
variable is correlated with the error term, violating strict exogeneity and leading to inconsistent estimates (Wooldridge, 2002).

This issue is dealt with in two alternative ways. First, the models are estimated including an indicator variable for whether the rating cell received a subsidy in the previous year. This variable is intended to account for systematic differences in costs for cells that received subsidies compared to those that did not, in the previous year. Second, instrumental variables (IV) estimation methods, in which the lagged subsidy or overcharge amount is treated as endogenous, are used. ${ }^{22}$ The excluded instruments are the subsidy and overcharge amounts that arise from the distribution of the residual marketoperating deficit across rating cells. As discussed previously, the residual market deficit is equally distributed across drivers, not in relation to the percentage of a rating cell's drivers insured in the residual market, nor in relation to the average subsidy or overcharge amount for the cell. As a result this portion of the subsidy or overcharge amount is not related to cell risk or to the dynamics of costs within the rating cell, but only to the dynamics of prices relative to costs in the market overall.

\section{Estimation results}

\section{The effect of cross-subsidies on insurance costs}

Estimation results are presented in Tables 6-8. Each table reports estimates using several different versions of control variables to examine the robustness of results to alternative specifications. Reported standard errors for all parameter estimates are robust to heteroskedasticity and to correlation within each rating cell across time.

Table 6 reports initial OLS estimates using the indicator of whether a subsidy is received in a given cell and year, or the percentage of drivers subsidized in a cell and year. The lagged subsidy indicator is positive and significant, suggesting that insurance costs are higher among rating cells and years that receive subsidies. The lagged percentage of drivers in the cell who received a premium subsidy at the state-set rates is also significant, and positively related to current insurance costs. The results are not sensitive to the inclusion of specific controls or class and territory trends: the signs, significances and estimated magnitudes of coefficients are similar across the different model specifications.

\footnotetext{
${ }^{22}$ Use of IV to instrument for subsidy and overcharge amounts can also correct errorsin-variables problems that arise due to the errors in the measurement of subsidy and overcharges.
} 


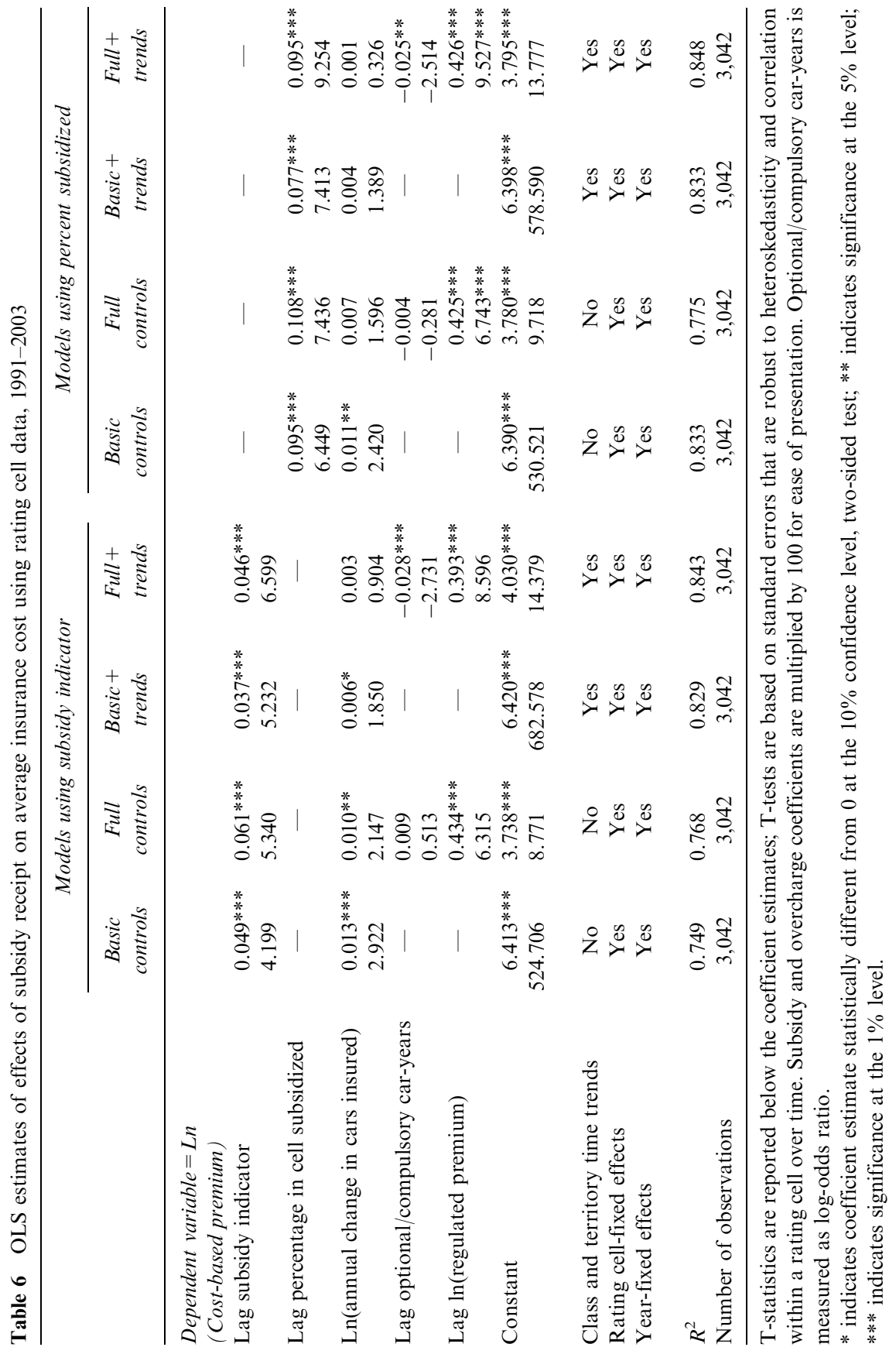




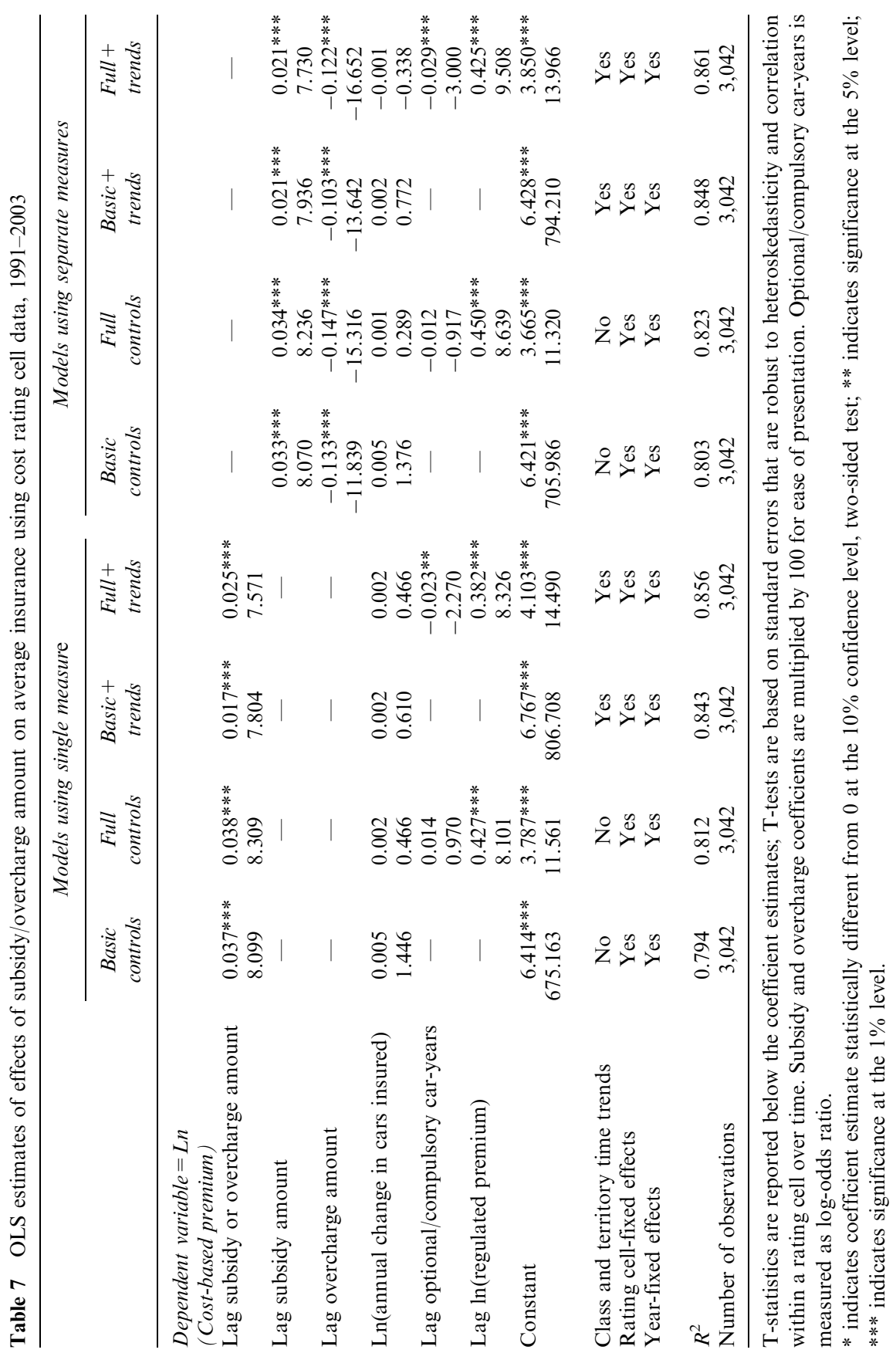


Table 8 Endogeneity corrected estimates of effects of subsidy/overcharge amount on average insurance cost using rating cell data, 1991-2003

\begin{tabular}{|c|c|c|c|c|}
\hline & \multicolumn{2}{|c|}{$\begin{array}{l}\text { Models using } \\
\text { indicator }\end{array}$} & \multicolumn{2}{|c|}{$\begin{array}{l}\text { Models using } \\
\quad 2 S L S\end{array}$} \\
\hline & $\begin{array}{c}\text { Full } \\
\text { controls }+ \\
\text { trends }\end{array}$ & $\begin{array}{c}\text { Full } \\
\text { controls }+ \\
\text { trends }\end{array}$ & $\begin{array}{c}\text { Full } \\
\text { controls }+ \\
\text { trends }\end{array}$ & $\begin{array}{c}\text { Full } \\
\text { controls }+ \\
\text { trends }\end{array}$ \\
\hline \multicolumn{5}{|l|}{$\begin{array}{l}\text { Dependent variable }=\text { Ln } \\
\text { (Cost-based premium) }\end{array}$} \\
\hline Lag subsidy or overcharge amount & $\begin{array}{l}0.023^{* * *} \\
7.573\end{array}$ & & $\begin{array}{l}0.054 * * * \\
3.327\end{array}$ & \\
\hline Lag subsidy amount & - & $\begin{array}{l}0.021 \text { *** } \\
7.718\end{array}$ & - & $\begin{array}{l}0.052^{* * *} \\
3.036\end{array}$ \\
\hline Lag overcharge amount & - & $\begin{array}{l}-0.110^{* * *} \\
-12.977\end{array}$ & - & $\begin{array}{l}-0.156 \\
-0.508\end{array}$ \\
\hline Lag subsidy indicator & $\begin{array}{l}0.033^{* * * *} \\
5.400\end{array}$ & $\begin{array}{l}0.014^{* *} \\
2.168\end{array}$ & - & - \\
\hline Ln(annual change in cars insured) & $\begin{array}{l}-0.001 \\
-0.308\end{array}$ & $\begin{array}{l}-0.001 \\
-0.308\end{array}$ & $\begin{array}{l}-0.006 \\
-1.561\end{array}$ & $\begin{array}{l}-0.006^{*} \\
-1.648\end{array}$ \\
\hline Lag optional/compulsory car-years & $\begin{array}{l}0.411 * * * \\
9.101\end{array}$ & $\begin{array}{l}-0.029 * * * \\
-3.005\end{array}$ & $\begin{array}{l}0.422 * * * \\
7.682\end{array}$ & $\begin{array}{l}0.469^{* * *} \\
3.540\end{array}$ \\
\hline Lag $\ln$ (regulated premium) & $\begin{array}{l}-0.025 * * * \\
-2.467\end{array}$ & $\begin{array}{l}0.432 * * * \\
9.721\end{array}$ & $\begin{array}{l}-0.020^{*} \\
-1.700\end{array}$ & $\begin{array}{l}-0.026 \\
-1.226\end{array}$ \\
\hline Constant & $\begin{array}{l}3.901 * * * \\
13.989\end{array}$ & $\begin{array}{l}3.792^{* * *} \\
13.820\end{array}$ & $\begin{array}{l}3.140^{* * * *} \\
10.890\end{array}$ & $\begin{array}{l}2.927^{* * *} \\
4.803\end{array}$ \\
\hline Class and territory time trends & Yes & Yes & Yes & Yes \\
\hline Rating cell-fixed effects & Yes & Yes & Yes & Yes \\
\hline Year-fixed effects & Yes & Yes & Yes & Yes \\
\hline$R^{2}$ & 0.859 & 0.864 & 0.991 & 0.986 \\
\hline Number of observations & 3,042 & 3,042 & 3,042 & 3,042 \\
\hline
\end{tabular}

T-statistics are reported below the coefficient estimates; T-tests are based on standard errors that are robust to heteroskedasticity and correlation within a rating cell over time. Subsidy and overcharge coefficients are multiplied by 100 for ease of presentation. Optional/compulsory car-years is measured as log-odds ratio.

* indicates coefficient estimate statistically different from 0 at the $10 \%$ confidence level, two-sided test; $* *$ indicates significance at the $5 \%$ level; $* * *$ indicates significance at the $1 \%$ level.

Table 7 reports OLS estimates using the measures of subsidy and overcharge amounts. The results strongly support the conclusion that premium subsidies increase insurance costs, and premium overcharges decrease insurance costs, at the rating cell level. This estimated relationship is seen in both the positive coefficient on the single measure of subsidy or overcharge and in the opposing signs of the estimated coefficients on subsidies and overcharges in the model 
that includes them separately. The estimates allowing different marginal effects of subsidies and overcharges show that both subsidies and overcharges are significantly related to insurance costs, and the impact of a one dollar change in each appears to be quite different. F-tests strongly reject the hypothesis that the estimated coefficients on the subsidy and overcharge variables are the same in absolute value. As was the case in the previous table, results are not sensitive to the inclusion of specific controls or class and territory trends, although the estimated coefficients on the subsidy and/or overcharge variables are somewhat smaller when class and territory time trends are included.

Table 8 presents estimates that account for the possibility of feedback effects from subsidies or overcharges. Only the fully specified models - with all controls and time trends - are reported in the table. Models that include the lagged subsidy indicator along with subsidy and overcharge amounts show that this indicator is positive and significant, consistent with the idea that subsidy receipt in the previous year is associated with higher costs in the current year. However, inclusion of the subsidy indicator does not reduce the significance of the subsidy and overcharge variables, and only slightly reduces the estimated coefficient magnitudes of these variables. Thus, subsidies and overcharges remain significantly associated with insurance costs in the predicted direction even after accounting for effects associated with being in a subsidy-receiving cell.

In the IV estimates, the lagged subsidy or overcharge variable remains significant and positively related to insurance costs, and the estimated magnitude is larger than that in the OLS estimates. ${ }^{24}$ In the estimates that include separate subsidy and overcharge variables, subsidies are positively related to costs and overcharges are negatively related to costs and the coefficient magnitudes are again larger than those estimated using OLS. However, only the subsidy variable remains statistically significant in these estimates.

\section{Estimated impact of cross-subsidies}

The results from the estimation can be translated directly into the implied changes in insurance costs due to changes in subsidy or overcharge amounts,

${ }^{24}$ For estimates using the combined subsidy/overcharge variable, the first-stage partial F-statistic for the significance of the excluded instruments is $\mathrm{F}(2,2758)=7.69$ ( $\mathrm{p}$-value $=0.0005$ ); the CraggDonaldson weak identification F-statistic is 73.19; and the Hansen $\mathrm{J}$ test of overidentifying restrictions is $\left(\chi^{2}(1)=0.113, \mathrm{p}\right.$-value $=0.716$. $)$ These tests support the relevance and validity of the instruments. For estimates using the separate subsidy and overcharge variables, the firststage partial F-statistics are $\mathrm{F}(2,2760)=7.10$ (p-value $=0.008$ ) for the subsidy equation and $F(2,2760)=5.49 \quad(\mathrm{p}$-value $=0.004)$ for the surcharge equation; the Cragg-Donaldson weak identification test statistic is 8.54 . This model is exactly identified. 
allowing one to gauge the responsiveness of insurance costs to changes in premium cross-subsidies. Estimates that include full controls and linear time trends suggest that rating cells receiving a premium subsidy experience costs that are 4.7 per cent $(\exp (0.046))$ higher than expected.

The estimated elasticity of costs with respect to subsidies is 0.032 and that with respect to overcharges is -0.015 . This implies that at the mean subsidy (overcharge) level for a driver at the mean level of cost, a doubling of the subsidy amount leads to a 3.2 per cent increase in costs; a doubling of the overcharge amount decreases costs by 1.5 per cent. Thus, the estimated impact of cross-subsidies on insurance costs, after controlling for other factors that affect costs, are small in economic terms.

It is worth emphasizing, however, that these are estimates of the marginal not the average - effects of subsidies and overcharges due to community rating restrictions. The estimates take the cumulative effects of the regulatory and driving environment as given, and measure only the impact of adjusting subsidy and overcharge amounts in that environment. Any effects of rating restrictions on insurance costs that arise due to distortions in the average propensity of drivers to engage in risk taking are not incorporated in these estimates. For example, any effects on Massachusetts drivers' choice of vehicles, garaging or housing location, insurance claiming behaviors or driving habits are not measured in this study.

\section{Robustness checks}

Several minor modifications to the empirical specifications are undertaken to test the robustness of the results, but are not reported here. The models are estimated measuring costs in levels rather than logs, and measuring both costs and subsidy/overcharge variables in logs. The signs and significances of key variables are similar in both cases.

The models are also estimated using data from only the experienced driver classes. Because data are available only at the rating cell level and not for individual drivers, the observed effect of subsidies on rating cell averages could arise either due to behavioral changes among insured drivers or to changes in the composition of the rating cell. The estimated models include a variable measuring the change in the number of cars insured as a proxy for cell composition changes. However, the inexperienced driver classes are among the most heavily subsidized, and by construction these cells also exhibit large turnover in drivers each year. Nonetheless, when estimated on the experienced driver sample, the signs and significances of the estimated relationships remain similar to those produced using the full sample of rating cells. This provides additional assurance that the results are not driven by changes in rating cell composition. 


\section{Conclusion}

This paper has tested for a relationship between regulated premium crosssubsidies and insurance costs in an automobile insurance market. The paper argues that regulated premium cross-subsidies reduce the safety incentives of subsidized high-risk consumers and increase those of overcharged low-risk consumers. This effect can lead to higher insurance costs for subsidized groups and lower costs for overcharged groups.

The empirical findings suggest that these incentive distortions are present in the regulated Massachusetts automobile insurance market. Using annual data from individual rating cells in Massachusetts over the time period 1991-2003, larger premium subsidies are associated with significantly higher insurance costs and larger premium overcharges with significantly lower insurance costs, in the following year. These findings are robust to controlling for time-varying and time-invariant characteristics of the rating cell, yearly shocks that affect all rating cells equally, linear time trends for each class and territory, and clustering of observations by rating cell. The results are also robust to treating the subsidy amount as jointly determined with insurance costs, although in this specification overcharge amounts are not significantly related to insurance costs.

One strength of this paper is the ability to provide a more complete test of theoretical predictions than in previous studies, by identifying cost responses to premium subsidies and overcharges separately. The main limitations of the paper arise from the nature of the data available for the study. Actuarial estimates of cost-based premiums are used to approximate loss costs, and systematic errors in cost estimates for the different rating cells could affect the estimates in this paper. The estimation results are robust to the inclusion of rating cell-fixed effects, year-fixed effects, class-specific time trends and territory-specific time trends; to exclusion of the highest risk rating cells; and to linear or log-linear specifications of the model. These checks provide some assurance that the estimated relationships are not merely statistical artifacts of the data.

The data also do not permit identification of direct behavioral changes caused by premium subsidies and overcharges. The observed effects of crosssubsidies could arise due to behavioral changes among insured drivers or to changes in the composition of insured rating cells. The empirical models include control variables to account for changes in cell risk composition, and supplementary regressions confirm that the impact of premium cross-subsidies on costs and insurance coverage remains the same when new drivers are eliminated from the sample. Moreover, the state's compulsory insurance law, the small number of rating factors allowed, and the lack of residual market surcharges reduce driver migration into and out of rating cells. These factors 
provide some additional confidence that the empirical findings reflect changes in drivers' behaviors.

The incentive distortions identified in this paper are not usually considered in discussions of regulatory restrictions on insurance prices and underwriting. Yet, where present, these distortions will increase the efficiency losses associated with the regulations. They may also have important dynamic implications for regulation. Premium cross-subsidies that lead to higher costs for subsidized high risks and to lower costs for overcharged low risks will further increase insurance cost differences between high-risks and low-risks over time. These forces have the potential to reinforce the perceived need for rating restrictions, perpetuating the system of cross-subsidies and the associated inefficiencies.

\section{References}

Abraham, K.S. (1985) 'Efficiency and fairness in insurance risk classification', Virginia Law Review 71: 403-451.

Automobile Insurers Bureau of Massachusetts (1990-2003) Actuarial Notice: Subsidies in the Rates, Boston, MA: AIB.

Automobile Insurers Bureau of Massachusetts (1998) 1999 Private Passenger Automobile Insurance Rates, Class/Territory Relativities, Boston, MA: AIB.

Bartlett III, D.K., Klein, R.W. and Russell, D.T. (1999) 'Attempts to socialize costs in voluntary insurance markets: The historical record', Journal of Insurance Regulation 17: 478-511.

Blackmon Jr., B.G. and Zeckhauser, R. (1991) 'Mispriced equity: Regulated rates for auto insurance in Massachusetts', American Economic Review 81: 65-69.

Boyer, M. and Dionne, G. (1989) 'An empirical analysis of moral hazard and experience rating', Review of Economics and Statistics 71: 128-134.

Buchmueller, T. and DiNardo, J. (2002) 'Did community rating introduce an adverse selection death spiral? Evidence from New York, Pennsylvania and Connecticut', American Economic Review 92: 280-294.

Chang, L. and Fairley, W.B. (1978) 'An estimation model for multivariate risk classification', in Automobile Risk Classification: Equity and Accuracy, Boston, MA: Massachusetts Division of Insurance.

Chang, L. and Fairley, W.B. (1979) 'Pricing automobile insurance under multivariate classification of risks: Additive versus multiplicative', Journal of Risk and Insurance 46: 75-98.

Crocker, K.J. and Bond, E. (1991) 'Smoking skydiving and knitting: The endogenous categorization of risks in insurance markets with asymmetric information', Journal of Political Economy 99: 177-200.

Crocker, K.J. and Snow, A. (1986) 'The efficiency effects of categorical discrimination in the insurance industry', Journal of Political Economy 94: 320-344.

Dahlby, B. (1983) 'Adverse selection and statistical discrimination: An analysis of Canadian automobile insurance', Journal of Public Economics 20: 121-130.

Dahlby, B. (1992) 'Testing for asymmetric information in Canadian automobile insurance', in G. Dionne (ed) Contributions to Insurance Economics, Boston: Kluwer Academic Publishers.

Danzon, P.M. and Harrington, S.E. (2001) 'Workers' compensation rate regulation: How price controls increase costs', Journal of Law and Economics 44: 1-36. 
Derrig, R.A. (1993) 'Price regulation in U.S. automobile insurance: A case study of Massachusetts private passenger automobile insurance 1978-1990', The Geneva Papers on Risk and Insurance 18: $158-173$.

Dionne, G. (2002) 'Insurance regulation in other industrial countries', in J.D. Cummins (ed) Deregulating Property-Liability Insurance AEI-Brookings, Washington, D.C.: Brookings Institution Press, pp. 362-390.

Dionne, G. and Ghali, O. (2005) 'The (1992) bonus-malus system in Tunisia: An empirical evaluation', Journal of Risk and Insurance 72(4): 609-633.

Finger, R.J. (2006) 'Risk classification', Foundations of Casualty Actuarial Science, Chapter 6. Casualty Actuarial Society, published at http://www.casact.org.

Finkelstein, A. and Poterba, J. (2004) 'Adverse selection in insurance markets: Policyholder evidence from the U.K. annuity market', Journal of Political Economy 112: 183-208.

Finkelstein, A., Poterba, J. and Rothschild, C. (2006) Redistribution by insurance market regulation: Analyzing a ban on gender based retirement annuities, NBER working paper (\#12205), Boston.

Grace, M.F., Klein, R.W. and Phillips, R.D. (2002) 'Auto Insurance Reform: Salvation in South Carolina', in J.D. Cummins, (ed) Deregulating Property-Liability Insurance, Washington, DC: Brookings Institution Press, pp. 148-194.

Harrington, S.E. (1991) 'Automobile insurance in Michigan: Regulation, no fault and affordability', Journal of Insurance Regulation 10: 144-183.

Harrington, S.E. and Danzon, P.M. (2000) 'Rate regulation, safety incentives and loss growth in workers compensation insurance', Journal of Business 73: 569-596.

Harrington, S.E. and Doerpinghaus, H.I. (1993) 'The economics and politics of automobile insurance rate classification', Journal of Risk and Insurance 60: 59-84.

Kapur, K. (2004) 'The impact of the health insurance market on small firm employment', Journal of Risk and Insurance 71: 63-90.

Keeton, W.R. and Kwerel, E. (1984) 'Externalities in automobile insurance and the underinsured driver problem', Journal of Law and Economics 27: 149-179.

Monheit, A.C. and Steinberg Schone, B. (2004) 'How has small group market reform affected employee health insurance coverage?' Journal of Public Economics 88: 237-254.

Monheit, A.C., Cantor, J.C., Koller, M. and Fox, K.S. (2004) 'Community rating and sustainable individual health insurance markets in New Jersey', Health Affairs 23: 167-175.

Pauly, M.V. (1970) 'The welfare economics of community rating', Journal of Risk and Insurance 37: 407-418.

Picard, P. (2008) 'National disaster insurance and the equity efficiency trade-off', Journal of Risk and Insurance 75: 17-38.

Rea, S.A. (1992) 'Insurance classifications and social welfare', in G. Dionne (ed) Contributions to Insurance Economics, Boston: Kluwer Academic Publishers.

Regan, L., Tennyson, S. and Weiss, M.A. (2008) 'The relationship between auto insurance rate regulation and insured loss costs: An empirical analysis', Journal of Insurance Regulation 27: 23-46.

Riley, J.G. (1979) 'Informational equilibrium', Econometrica 47: 331-359.

Rothschild, M. and Stiglitz, J.E. (1976) 'Equilibrium in competitive insurance markets: An essay on the economics of imperfect information', Quarterly Journal of Economics 90: 629-649.

Rottenberg, S. (1989) The Cost of Regulated Pricing: A Critical Analysis of Auto Insurance Premium Rate-Setting in Massachusetts, Boston: Pioneer Institute for Public Policy Research.

Shavell, S. (1986) 'The judgment proof problem', International Review of Law and Economics 6: $45-58$.

Simon, K. (2005) 'Adverse selection in health insurance markets? Evidence from state small-group health insurance reforms', Journal of Public Economics 89: 1865-1877. 
Smith, E. and Wright, R. (1992) 'Why is automobile insurance in Philadelphia so damn expensive?' American Economic Review 82: 756-772.

Stone, J.M. (1978) Opinion, Findings and Decision on the Operation of Competition Among Motor Vehicle Insurers Rendered, Boston, MA: Massachusetts Division of Insurance.

Swartz, K. and Garnick, D.W. (1999) 'Can adverse selection be avoided in a market for individual health insurance?' Medical Care Research and Review 56: 373-388.

Tennyson, S. (1997) 'The impact of rate regulation on state automobile insurance markets', Journal of Insurance Regulation 15(4): 502-523.

Tennyson, S., Weiss, M.A. and Regan, L. (2002) 'Automobile insurance regulation: The Massachusetts experience', in J.D. Cummins (ed) Deregulating Property-Liability Insurance: Restoring Competition and Increasing Market Efficiency, Washington, D.C.: AEI-Brookings Joint Center for Regulatory Studies.

Weiss, M.A., Tennyson, S. and Regan, L.R. (2010) 'The effects of regulated premium subsidies on insurance costs: An empirical analysis of automobile insurance', Journal of Risk and Insurance, forthcoming.

Wilson, C. (1977) 'A model of insurance markets with incomplete information', Journal of Economic Theory 16: 167-207.

Wooldridge, J.W. (2002) Econometric Analysis of Cross Section and Panel Data, Cambridge: MIT Press.

Yelen, S. (1993) 'Withdrawal restrictions in the automobile insurance market', The Yale Law Journal 102: 1431-1455.

\section{Appendix}

The marginal effect of premium subsidies and overcharges on driver safety incentives under Massachusetts regulations is derived using the following illustrative model of driver choice of safety.

Consider a risk-averse driver who faces potential loss $L$. The exogenous ex ante probability of this loss occurring is equal to $r$, with $0<r<1$. The driver makes choices that modify this exogenous probability of loss; specifically he may choose to engage in safe driving behaviors $s$, where $0<s<1$, that modify the probability of loss by $(1-s)$. His endogenously determined probability of loss is thus $r(1-s)$ and the probability of no loss is $1-r(1-s)$.

The driver makes decisions to maximize his expected utility. The driver's utility function of wealth is $U(Y)$, with $U^{\prime}>0$ and $U^{\prime \prime}<0$, where $Y$ denotes wealth. Behaving carefully yields a psychic disutility cost of $s^{2}$. The driver's utility is linearly separable in $Y$ and $s$.

The driver is required by the state's compulsory insurance law to purchase insurance. Assume for simplicity that the required amount of insurance coverage, $X$, provides full insurance (i.e. $X=L$ ). Denote the ex ante cost-based premium for this risk by $P(r, L) . P$ is a function of $r$ instead of $r(1-s)$ due to state restrictions on rating factors. Also, due to state regulations, the driver does not pay $P$ but instead pays $\gamma P, \gamma>0$. A parameter value $\gamma>1$ implies that the driver pays an overcharge; $\gamma<1$ implies that the driver receives a subsidy. If the driver 
has an accident in the current period his premium in the next period will increase to $c \gamma P$, where $c>1$ and is determined by state regulations.

Assume for simplicity that the driver has a two period time horizon, and discounts utility across time at a rate of $\delta$. Then the driver chooses the level of care $\mathrm{s}$ in period 1 to maximize:

$$
\begin{aligned}
U(Y-\gamma P)-s^{2} & +\delta\{r(1-s) U(Y-c \gamma P) \\
+ & (1-r(1-s)) U(Y-\gamma P)\} .
\end{aligned}
$$

Investments in $s$ reduce current utility due to the psychic costs of taking care. However, a higher level of $s$ reduces the probability of a loss in the current period, which reduces the probability of having to pay the premium surcharge $c$ in the next period. Thus, the driver faces a trade-off between current utility (of driving) and future expected utility (of income).

The first order condition for the driver's utility maximization problem is

$$
\delta r\{U(Y-\gamma P)-U(Y-c \gamma P)\}=2 s,
$$

which implies choosing the value of $s^{*}$ to equalize the marginal cost of care $(2 s)$ and the marginal benefit of care, where the marginal benefit of care is the discounted expected value of the gain in next period's utility due to avoiding the accident surcharge on the insurance premium.

We are interested in how incentives to invest in care $\left(s^{*}\right)$ vary with regulatory subsidies and overcharges $(\gamma)$. Solving Eq. (A.2) for s and differentiating with respect to $\gamma$ yields

$$
\frac{\partial s^{*}}{\partial_{\gamma}}=-\frac{1}{2} \delta r P\left\{U^{\prime}(Y-\gamma P)-c U^{\prime}(Y-c \gamma P)\right\} .
$$

Because $U^{\prime}$ is negative, $Y-\gamma P$ is greater than $Y-c \gamma P$ and $c$ is greater than 1 , we know that the term in brackets is less than 0 . Thus, the optimal level of care $s^{*}$ is increasing in $\gamma$. Drivers who are overcharged have greater incentives to invest in safe driving than drivers who receive subsidies.

\section{About the Author}

Sharon Tennyson is Associate Professor in the Department of Policy Analysis and Management at Cornell University. She has published extensively on 
topics related to insurance rate regulation and insurance fraud, and is a frequent speaker on these issues. She serves on the editorial boards of the Journal of Risk and Insurance, the Journal of Insurance Regulation and Insurance Markets and Companies: Analyses and Actuarial Computations, and is a past president of the Risk Theory Society. Dr. Tennyson received her Ph.D. in economics from Northwestern University, and was previously on the faculty at the Wharton School of the University of Pennsylvania. 